\title{
Front Matter: Volume 11784
}

, "Front Matter: Volume 11784," Proc. SPIE 11784, Optics for Arts, Architecture, and Archaeology VIII, 1178401 (16 July 2021); doi: 10.1117/12.2603208

SPIE. Event: SPIE Optical Metrology, 2021, Online Only 


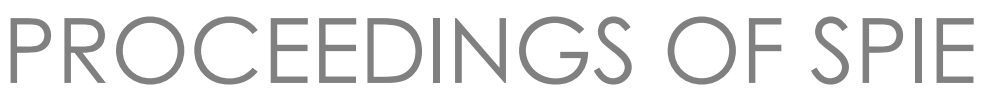

\title{
Optics for Arts, Architecture, and Archaeology VIII
}

\author{
Haida Liang \\ Roger Groves \\ Editors
}

21-25 June 2021

Online Only, Germany

Sponsored by

SPIE

Cooperating Organisations

European Optical Society

German Scientific Laser Society (Wissenschaftliche Gesellschaft Lasertechnik e.V.)

Published by

SPIE 
The papers in this volume were part of the technical conference cited on the cover and title page. Papers were selected and subject to review by the editors and conference program committee. Some conference presentations may not be available for publication. Additional papers and presentation recordings may be available online in the SPIE Digital Library at SPIEDigitalLibrary.org.

The papers reflect the work and thoughts of the authors and are published herein as submitted. The publisher is not responsible for the validity of the information or for any outcomes resulting from reliance thereon.

Please use the following format to cite material from these proceedings:

Author(s), "Title of Paper," in Optics for Arts, Architecture, and Archaeology VIII, edited by Haida Liang, Roger Groves, Proc. of SPIE 1 1784, Seven-digit Article CID Number (DD/MM/YYYY); (DOI URL).

ISSN: 0277-786X

ISSN: 1996-756X (electronic)

ISBN: 9781510644021

ISBN: 9781510644038 (electronic)

Published by

SPIE

P.O. Box 10, Bellingham, Washington 98227-0010 USA

Telephone +1 3606763290 (Pacific Time)

SPIE.org

Copyright (C) 2021 Society of Photo-Optical Instrumentation Engineers (SPIE).

Copying of material in this book for internal or personal use, or for the internal or personal use of specific clients, beyond the fair use provisions granted by the U.S. Copyright Law is authorized by SPIE subject to payment of fees. To obtain permission to use and share articles in this volume, visit Copyright Clearance Center at copyright.com. Other copying for republication, resale, advertising or promotion, or any form of systematic or multiple reproduction of any material in this book is prohibited except with permission in writing from the publisher.

Printed in the United States of America by Curran Associates, Inc., under license from SPIE.

Publication of record for individual papers is online in the SPIE Digital Library.

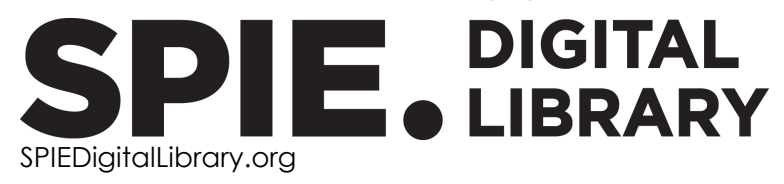

Paper Numbering: A unique citation identifier (CID) number is assigned to each article in the Proceedings of SPIE at the time of publication. Utilization of CIDs allows articles to be fully citable as soon as they are published online, and connects the same identifier to all online and print versions of the publication. SPIE uses a seven-digit CID article numbering system structured as follows:

- The first five digits correspond to the SPIE volume number.

- The last two digits indicate publication order within the volume using a Base 36 numbering system employing both numerals and letters. These two-number sets start with 00, 01, 02, 03, 04, 05, 06, 07, 08, 09, OA, OB ... 0Z, followed by 10-1Z, 20-2Z, etc. The CID Number appears on each page of the manuscript. 


\section{Contents}

MACHINE LEARNING AND DATA VISUALISATION

1178404 Reflectance hyperspectral data processing on a set of Picasso paintings: which algorithm provides what? A comparative analysis of multivariate, statistical and artificial intelligence methods (Invited Paper) [11784-1]

1178407 Deep learning for the extraction of sketches from spectral images of historical paintings [11784-4]

1178408 Analysis of craquelure patterns in historical paintings using image processing along with neural network algorithms [1 1784-5]

1178409 Intelligent labeling of areas of wall painting with paint loss disease based on multi-scale detail injection U-Net [1 1784-6]

IMAGING AND SPECTROSCOPY INSTRUMENT AND METHOD DEVELOPMENT

$11784 \mathrm{OE}$ Processing and analysis of THz time-domain spectroscopy imaging applied to cultural heritage [11784-12]

DEFORMATION AND STRUCTURAL ANALYSIS

11784 OG A novel method based on digital holographic interferometry (DHI) to in-situ register the dynamic behavior of concrete 20th century building heritage [1 1784-14]

$11784 \mathrm{OH} \quad$ Classification of surface geometry behaviour of cultural heritage surfaces based on monitoring change [11784-15]

$11784 \mathrm{Ol} \quad$ A simple method for artworks monitoring by simultaneous speckle interferometry (ESPI) and speckle photography [11784-16]

11784 OK Application of shearography and the percussion method for the structural inspection of wall paintings: a case study of St. Christopher in Maria Church, Nisse [1 1784-18]

\section{D TOMOGRAPHY}

$117840 Q \quad$ Three-dimensional spectral measurements of paint samples using optical coherence tomography (Invited Paper) [1 1784-24]

11784 OR Evaluation of art subjects in near-infrared spectral range by the optical coherence microscopy method [11784-25] 
11784 OS X-ray high resolution computed tomography for cultural heritage material micro-inspection [1 1784-26]

11784 OT Sub-surface damage detection in marble structures using THz time domain and laser feedback interferometric imaging techniques [11784-27]

GROUND-BASED AND AIRBORNE REMOTE IMAGING AND SPECTROSCOPY

11784 OW Improved detection of buried archaeological sites by fast hyperspectral image deblurring and denoising [11784-31]

\section{APPLICATIONS TO ART, ARCHAEOLOGY, ARCHITECTURE AND ANTHROPOLOGY}

$11784 \mathrm{OZ} \quad$ A multispectral design for a new generation of film scanners [1 1784-34]

1178410 Thermal imaging in the 3-5 micron range for precise localization of defects: application on frescoes at the Sforza Castle [11784-36]

\section{D SURFACE ANALYSIS}

1178415 An in-depth insight of the mechanical response of cellulose fibres by means of optical profilometry techniques [11784-41]

$1178416 \quad$ Fluorescence transformation imaging [1 1784-42]

1178417 2D and 3D ultraviolet fluorescence applications on cultural heritage paintings and objects through a low-cost approach for diagnostics and documentation [11784-43]

1178418 Color digital image correlation method for monitoring of cultural heritage objects with natural texture [1 1784-44]

\section{POSTER SESSION}

11784 1B Optimizing multicoloured LEDs for identifying pigments [11784-47]

11784 1E An application of near-infrared reflectance imaging spectroscopy on historical studies: differentiation of painting ground layers from the 15 th and 16 th centuries [11784-50]

$11784 \mathrm{IF} \quad$ Hyperspectral imaging workflow for the acquisition and analysis of stained-glass panels [1 1784-51]

iv 